\title{
Vitamin D3 Deficiency
}

National Cancer Institute

\section{Source}

National Cancer Institute. Vitamin D3 Deficiency. NCI Thesaurus. Code C128265.

Abnormally low concentration of vitamin D3 (cholecalciferol) in the blood. 